\title{
DENDROCHRONOLOGICAL DATING OF EASTERN RED CEDAR (JUNIPERUS VIRGINIANA L.) LOGS FROM ALFRED'S CABIN, THE HERMITAGE, HOME OF PRESIDENT ANDREW JACKSON
}

\author{
DANIEL B. LEWIS ${ }^{1}$, WHITNEY L. NELSON ${ }^{1}$, HENRI D. GRISSINO-MAYER ${ }^{1 *}$, EDWARD R. COOK ${ }^{2}$, and \\ ROBBIE D. JONES ${ }^{3,4}$ \\ ${ }^{1}$ Laboratory of Tree-Ring Science, Department of Geography, The University of Tennessee, Knoxville, Tennessee $37996-$ \\ 0925, USA \\ ${ }^{2}$ Tree-Ring Laboratory, Lamont-Doherty Earth Observatory, Columbia University, Palisades, New York 10964-1000, USA \\ ${ }^{3}$ Director of Preservation, The Hermitage, Home of President Andrew Jackson, 4580 Rachel's Lane, Nashville, \\ Tennessee 37076, USA
}

\begin{abstract}
Alfred Jackson was an enslaved African American born on The Hermitage plantation (outside Nashville, Tennessee) of President Andrew Jackson around 1810, and lived most of his life on the plantation. Staff from The Hermitage wished to better understand and interpret lifeways of those once enslaved on the plantation, but the date of construction of Alfred's Cabin first had to be determined. Was it built when Alfred was enslaved or was a freedman? We extracted nearly 100 core samples from eastern red cedar logs used to construct the cabin. Of these, 39 cores were used to develop a master tree-ring chronology for the cabin. Crossdating of the Alfred's Cabin chronology was accomplished using an eastern red cedar chronology developed by the Lamont-Doherty Earth Observatory TreeRing Laboratory at Columbia University in Palisades, New York. The 39 series from Alfred's Cabin resulted in a high-quality master tree-ring chronology, with an average inter-series correlation of 0.66 and an average mean sensitivity of 0.28 . Graphical (skeleton plot and line plot) comparison and statistical crossdating with COFECHA anchored the Alfred's Cabin chronology firmly between 1749 and $1842(\mathrm{r}=0.45, \mathrm{n}=94 \mathrm{yrs}, \mathrm{t}=4.83, \mathrm{p}<0.0001)$. Cutting dates of these 39 trees ranged from 1841 to 1843 . This latter date indicates that the final trees used to construct the cabin were harvested in spring or early summer of 1843 , with final construction of Alfred's Cabin occurring soon after.
\end{abstract}

Keywords: Tree rings, dendroarchaeology, construction history, log cabins, Alfred's Cabin, The Hermitage, Tennessee.

\section{INTRODUCTION}

Dendroarchaeological techniques have been extensively applied to date historic and prehistoric sites and structures in the Southwestern U.S. (Robinson 1976; Ahlstrom et al. 1991; Dean 1997; Nash 2000; Towner 2002; Bekker and Heath 2007), but only recently have these techniques been applied to sites and Structures in the Southeastern U.S. Here, dendrochronology has

* Corresponding author: grissino@utk.edu; Fax 865974-6029; Telephone 865-974-6029

${ }^{4}$ Current address: Senior Architectural Historian, Parsons Brinckerhoff, 1900 Church Street, Suite 203, Nashville, Tennessee 37203, USA been most successful at determining the years of construction for historic-period structures (Stahle 1979; McCrea 1995; Pulice 2000; Bortolot et al. 2001; Mann 2002; Reding 2002; Wight and Grissino-Mayer 2004; Grissino-Mayer and van de Gevel 2007) rather than prehistoric sites because the latter often do not have well-preserved wood samples or, if they do, the number of rings, type of wood (diffuse porous), and/or tree species preclude successful application of tree-ring dating techniques. Dendrochronological techniques are rapidly becoming the preferred method for dating historic structures constructed primarily of wood in the southeastern U.S. because a growing need exists to authenticate and verify reported con- 


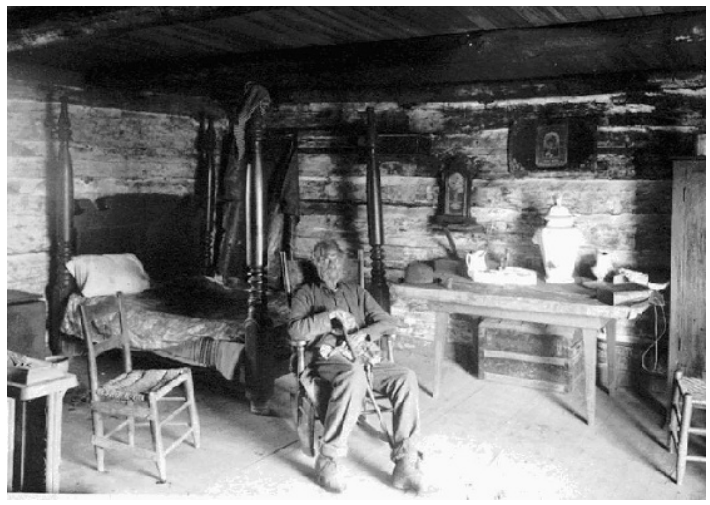

Figure 1. Alfred Jackson shown sitting in his log cabin ca. 1900 (photograph courtesy of The Hermitage).

struction dates (McCrea 1995; Bannatyne 2005; Rosman 2005; Grissino-Mayer and van de Gevel 2007). Occasionally, these reported dates of construction are suspect or erroneous (Mann 2002; Grissino-Mayer and van de Gevel 2007; Henderson et al., 2009; Slayton et al., 2009), and dendrochronology can be used to ensure historical accuracy.

The Hermitage, Home of President Andrew Jackson, is located ca. 15 miles $(23 \mathrm{~km})$ east of Nashville, Tennessee. Since 1889, over 15 million people have visited The Hermitage to view the historic mansion and its farm, to discover the life stories of Andrew Jackson, his family, and those enslaved who worked the farm, and to learn of efforts to preserve the many buildings on the property (The Hermitage 2008). Jackson's plantation was about 1,000 acres ( $c a .400$ ha) in size at its height, with many enslaved African Americans making up the work force. Approximately 10 slave cabins have been documented that are either still standing or once stood in the 1820 s to 1840 s. These 10 cabins housed approximately 22 enslaved families or between 132 to 176 individuals, considering the average enslaved family contained 6 to 8 people (McKee 2000). Jackson is said to have owned approximately 150 enslaved African Americans in the 1840s (Jones 2006).

The cabin of one of those enslaved, Alfred Jackson (Figure 1), is the primary focus of this study. Alfred was born at The Hermitage around 1810. By the 1830s, Alfred had become the plantation "waggoner" $[\mathrm{sic}]$ responsible for all

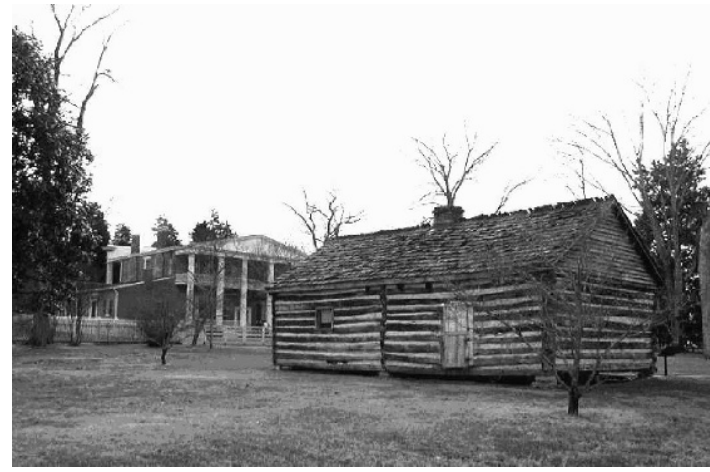

Figure 2. Alfred's cabin (east side), located behind the mansion at The Hermitage (photograph courtesy of The Hermitage).

farm equipment (Jones 2006). After President Andrew Jackson's death in 1845, the son of President Jackson, Andrew Jackson, Jr., experienced financial problems with The Hermitage and briefly sent Alfred to other farms in the South owned by the Jackson family. To ensure that Alfred's family remained at The Hermitage and out of the hands of creditors, Jackson in 1854 deeded to his wife Sarah, Alfred, his wife Gracy, and their two children (Jones 2006). After emancipation, Alfred's family stayed at The Hermitage, where he eventually worked as a tour guide and interpreter of the Jackson property in the late 1800s. By the 1890s, Alfred Jackson had become a celebrity among journalists eager to interview him for his vivid recollections of plantation life of the enslaved people (Jones 2006). Alfred lived his entire life at The Hermitage and died 4 September 1901. He was buried alongside the tomb of President Jackson and Jackson's wife Rachel.

Alfred's Cabin is a $19^{\text {th }}$ Century vernacular, double-pen, saddlebag-type (i.e. a central chimney with back-to-back fireplaces heating two rooms) $\log$ cabin located in the mansion backyard area (Figure 2). Between 1895 and 1897, the Ladies Hermitage Association (who own and operate the site then and now) made some initial repairs to the cabin and routinely maintained the cabin throughout the $20^{\text {th }}$ Century (Jones 2006). A major restoration of the cabin took place in 1981 and 1982. Some deteriorated logs may have been replaced, either partially or completely throughout the lifetime of the cabin. In 1960, the cabin was 
recognized as a National Historic Landmark and in 1966 was listed on the National Register of Historic Places. Recent research at Alfred's Cabin involved archaeological excavations (McKee 1997), construction and finish analyses (Reed 2000), a historic buildings survey (National Park Service 1999), and a cultural resources inventory (Jones 2002). Although these studies were of great importance, the true age of Alfred's Cabin could never be confirmed because no written records exist that note when the cabin was built. Based on its architecture, the cabin was believed to have been built while Alfred Jackson was enslaved (Jones 2006), and it was assigned a preliminary date of "ca. 1840s", although the possibility existed that the structure was built as late as the 1860 s to 1870 s (Jones 2002).

The primary objective of the research presented here was to use dendrochronological techniques to date the years of harvest of trees used to construct Alfred's Cabin. Obtaining an absolute construction date for Alfred's Cabin has important implications for the history of the South for three reasons. First, the construction date could be important to the African American history of the region because, to date, no documented quarters of those enslaved in the southeastern U.S. (Virginia to Florida, South Carolina to Arkansas) have been dated using dendrochronological techniques. Second, dendrochronology has the potential to make a significant contribution by establishing tree-ring chronologies that can be used to study changes/continuities in floor plans, cabin sizes, wood types exploited over time, and persistence (or lack thereof) of architectural features, such as notch types. Third, obtaining absolute dates for the cabin will help guide future restoration work and interpretative programs given by staff of The Hermitage to help improve their portrayal of the lifeways of enslaved African Americans.

Our tree-ring study, however, was not the first conducted at The Hermitage. Bowers and Grashot (1976) attempted to date structures in the First Hermitage, the original, simple log structures used by President Jackson and his family from $c a$. 1804 to 1821 while the mansion of The Hermitage was being built. Although the dating was unsuc- cessful, their study represented the first modern attempt at dating a historic-period structure using dendrochronology in the Southeastern U.S. (see, however, Lassetter (1938) who dated log buildings in the Clinch River area of eastern Tennessee). Later, Heikkenen (2001) successfully dated the First Hermitage farmhouse to $1798-1800$ and the First Hermitage kitchen to 1805-1806.

\section{METHODS}

\section{Field Methods}

We first visually inspected the logs in the cabin to isolate logs that may have been replaced (these were not sampled), but found that nearly all logs in the cabin appeared to be original (with the possible exception of the sill logs) and were hewn from eastern red cedar (Juniperus virginiana L.) trees. Eastern red cedar was not a preferred tree species for log cabin construction in the Southeastern U.S. (oak species and tulip poplar were), but its use in this cabin may be related to the nearby presence of "cedar glades" (Baskin and Baskin 2004), and because Juniperus species are known to be impervious to decay compared to other conifers (Forest Products Laboratory 1974).

Each pen was assigned a number, the north side being "AC1" and the south side being "AC2." The cabin sides were labeled according to cardinal directions, with the west side being the front door entrance and the south side being closest to The Hermitage mansion. The logs were numbered sequentially starting with the bottom $\log$ and continuing up to the top log on each side of each pen. For example, the core identification "AC1W002A" would refer to Alfred's Cabin north pen ("ACl"), west side ("W"), $\log 2$ (the $\log$ above the sill $\log$ ), core "A."

Cores were extracted from each end of the log (basal and distal) (Figure 3). The extraction of at least two cores per log is desirable because (1) occasionally the ring patterns on an individual core may be erratic related to internal defects (especially for eastern red cedar that has lobate growth), (2) sometimes it was not obvious which end of the log was the basal end (and would therefore have the most rings), and (3) the averaging of measurements obtained from two 


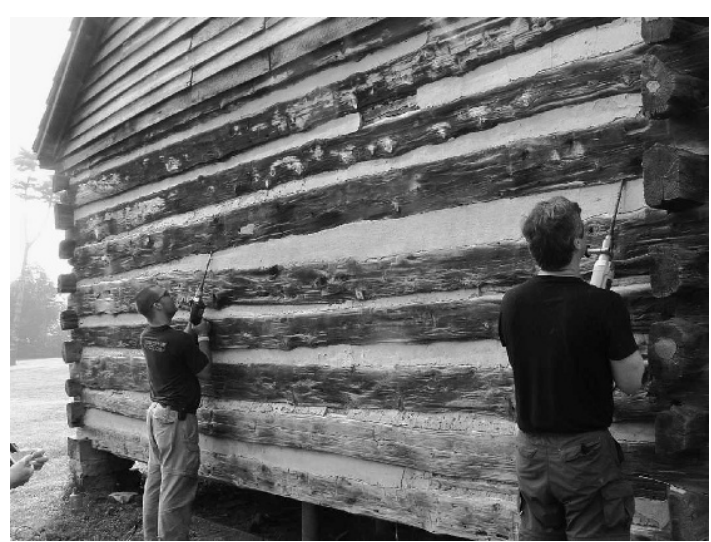

Figure 3. Cores being extracted from log AC1N006 on the north side of Alfred's Cabin (photograph by Whitney L. Kocis). This $\log$ was cut sometime between fall of 1841 and spring of 1842 .

cores per tree reduces the intra-tree variability that naturally occurs. A few cores were extracted from the central wall that separated the two pens and labeled "ACM." All cores were extracted using a custom-designed 0.5 -inch $(13 \mathrm{~mm})$ hollow wood borer attached to a variable speed hand drill. Once extracted, each core was glued on a speciallydesigned core mount using wood glue and fastened using masking tape. Each mounted core was appropriately labeled and all relevant information for the $\log$ and core was recorded on standard sample forms.

\section{Graphical Crossdating}

Each core was surfaced beginning with ANSI 40-grit (500-595 $\mu \mathrm{m})$ and progressing up to ANSI 400-grit $(20.6-23.6 \mu \mathrm{m})$ using a $4 \times 24$ inch belt sander (Orvis and Grissino-Mayer 2002) to ensure that the cellular structure of the tree rings was visible under standard magnification. We then created skeleton plots from cores that had the clearest ring sequences (what we term "type" cores) to graphically crossdate the tree rings between cores (Swetnam et al. 1985; Stokes and Smiley 1996), a process known as "internal crossdating" (Grissino-Mayer and van de Gevel 2007). This process also helped identify "signature" ring patterns and marker rings (Nielson et al. 1995) that could be used to date the more erratic ring sequences, using the list method of crossdating (Yamaguchi 1991). We then measured all tree-ring widths for each series to the nearest $0.001 \mathrm{~mm}$ using a movable-stage Velmex micrometer and Measure J2X software.

We then compared the individual skeleton plots for the Alfred's Cabin cores against a skeleton plot created from an eastern red cedar reference chronology recently developed for the Norris Basin area of eastern Tennessee ("external crossdating"). The Norris Basin reference chronology was constructed from living eastern red cedar trees collected by staff of the LamontDoherty Earth Observatory at Columbia University in 2003, and from living trees and remnant eastern red cedar samples collected by Dr. Florence Hawley of the University of Chicago before the basin was flooded by the Tennessee Valley Authority in 1937 (Hawley 1937, 1938, 1941). The Norris Basin reference chronology contains 47 dated series that span from 1378 to 2002, has an average inter-series correlation of 0.49 , and an average mean sensitivity of 0.30 , both values being very high by southeastern dendrochronological standards.

\section{Statistical Crossdating}

To verify the graphical crossdating on our cores, we used COFECHA, a quality-control program that uses segmented time-series correlation techniques to statistically confirm the temporal placements of all tree rings (Holmes 1983; Grissino-Mayer 2001). COFECHA begins by first removing all low-frequency trends in each measured series using both spline-fitting algorithms and autoregressive modeling (Grissino-Mayer 2001). These low-frequency trends are most often caused by normal physiological aging processes within each individual tree, and can mask the climate signal desirable for accurate crossdating. To accomplish the necessary two-step process of verifying both the internal crossdating (between cores) and the external crossdating (anchoring the undated cores using the reference chronology), COFECHA calculated correlation coefficients for consecutive 40-yr segments (with 20-yr overlaps) for each individual series compared first against a temporary master chronology created from all other series (for internal crossdating) and then 


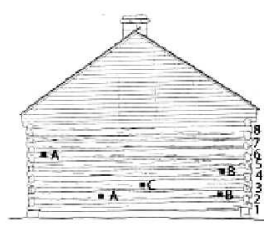

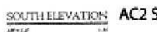

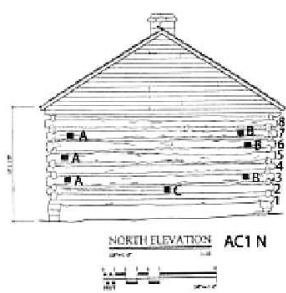

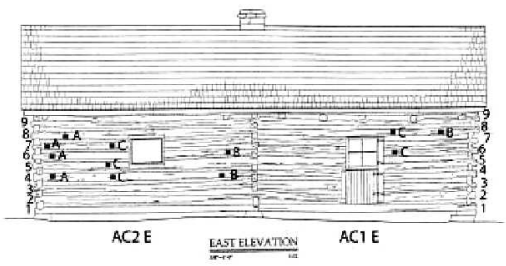

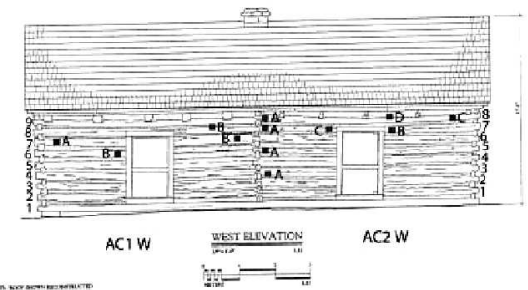

Figure 4. Sketch of Alfred's cabin showing the numbering sequence of the logs and pen identification. Dots represent locations of crossdated samples and their core letters (A-D) used to construct the Alfred's Cabin master chronology (original figure from the Historic American Buildings Survey, National Park Service, 1999).

against the reference chronology (for external crossdating). Internal crossdating was verified when the correlation coefficient for each tested segment exceeds $0.37(\mathrm{p}<0.01)$, although correlation coefficients were usually much higher (for example, $r>0.55, p<0.0001)$. External crossdating was accomplished when 40-yr segments of the master chronology for the Alfred's Cabin cores required no shift from their dated position for the majority of segments tested (Grissino-Mayer 2001).

\section{RESULTS}

One hundred cores were extracted from Alfred's Cabin. As expected for Juniperus species, not all of the cores from Alfred's Cabin could be used for various reasons nor could others be crossdated successfully against the Norris Basin master chronology. Of these 100, 28 cores did not have sapwood, or did have sapwood but it was detached from the heartwood, or were broken in several pieces, and these were not processed further after collection. Of the remaining 78 cores, some were extracted from logs with either internal defects (enclosed branches and/ or knots, common in Juniperus species) or included bark (because of the lobate growth form of Juniperus species) that precluded their use. Other cores showed too few rings for successful crossdating after sanding. Nonetheless, 39 cores from 24 logs (Figure 4) showed convincing graphical and statistically significant crossdating (Table 1) both internally against each other and externally against the Norris Basin reference chronology to consider them anchored absolutely in time. Internal crossdating was further achieved by noting critical marker rings in each core, such as the narrow rings in 1772 and 1773, 1784, 1799, 1826 and 1828, and 1836, and the prominent false ring in 1830 .

\section{Crossdating}

The average mean sensitivity (a measure of the year-to-year variability in ring widths needed for successful crossdating) was 0.28 , which is similar to the average mean sensitivity of the Norris Basin master chronology (0.30), and very good for southeastern tree-ring chronologies. The average inter-series correlation for the cores from Alfred's Cabin was 0.66, which is above the minimum correlation of 0.46 often used to assess the quality of internal crossdating among series from a site (Grissino-Mayer and Fritts 1997). The lowest series correlation was 0.48 (for core $\mathrm{AC} 2 \mathrm{~S} 003 \mathrm{C}$ ) while the highest was 0.86 (for core AC1E006C). These statistics attest to the high quality of these eastern red cedar tree rings for dendrochronological dating. 
Table 1. Correlation matrix from COFECHA, demonstrating the crossdating in the tree-ring patterns from cores extracted from Alfred's Cabin.

\begin{tabular}{|c|c|c|c|c|c|c|c|c|}
\hline & \multirow[b]{2}{*}{ Series } & \multirow{2}{*}{$\begin{array}{c}\text { Begin } \\
\text { Year }\end{array}$} & \multirow{2}{*}{$\begin{array}{l}\text { End } \\
\text { Year }^{2}\end{array}$} & \multicolumn{5}{|c|}{$40-Y r$ Segment ${ }^{1}$} \\
\hline & & & & $1740-1779$ & $1760-1799$ & $1780-1819$ & $1800-1839$ & $1820-1859$ \\
\hline 1 & $\mathrm{AC} 1 \mathrm{E} 006 \mathrm{C}$ & 1770 & 1841 & & 0.90 & 0.87 & 0.78 & 0.77 \\
\hline 2 & AC1E008B & 1772 & 1841 & & 0.79 & 0.79 & 0.53 & 0.44 \\
\hline 3 & $\mathrm{AC} 1 \mathrm{E} 008 \mathrm{C}$ & 1772 & 1842 & & 0.80 & 0.79 & 0.50 & 0.47 \\
\hline 4 & $\mathrm{AC} 1 \mathrm{~N} 002 \mathrm{C}$ & 1769 & 1842 & & 0.58 & 0.49 & 0.46 & 0.52 \\
\hline 5 & AC1N003A & 1771 & 1842 & & 0.53 & 0.50 & 0.51 & 0.55 \\
\hline 6 & AC1N003B & 1783 & 1840 & & & 0.65 & 0.57 & 0.58 \\
\hline 7 & AC1N005A & 1774 & 1840 & & 0.80 & 0.79 & 0.46 & 0.46 \\
\hline 8 & AC1N006B & 1794 & 1840 & & & 0.48 & 0.47 & 0.48 \\
\hline 9 & AC1N007A & 1771 & 1841 & & 0.92 & 0.84 & 0.60 & 0.58 \\
\hline 10 & AC1N007B & 1780 & 1841 & & & 0.61 & 0.77 & 0.75 \\
\hline 11 & AC1W006B & 1749 & 1841 & 0.77 & 0.74 & 0.64 & 0.65 & 0.66 \\
\hline 12 & AC1W007A & 1780 & 1841 & & & 0.62 & 0.48 & 0.40 \\
\hline 13 & AC1W007B & 1780 & 1841 & & & 0.62 & 0.54 & 0.48 \\
\hline 14 & AC1W008B & 1775 & 1840 & & 0.80 & 0.80 & 0.59 & 0.60 \\
\hline 15 & AC1W008C & 1779 & 1841 & & 0.83 & 0.84 & 0.56 & 0.56 \\
\hline 16 & AC2E004A & 1769 & 1841 & & 0.59 & 0.55 & 0.76 & 0.79 \\
\hline 17 & $\mathrm{AC} 2 \mathrm{E} 004 \mathrm{~B}$ & 1774 & 1842 & & $0.50 \mathrm{~B}$ & 0.63 & 0.72 & 0.72 \\
\hline 18 & $\mathrm{AC} 2 \mathrm{E} 004 \mathrm{C}$ & 1771 & 1841 & & 0.59 & 0.45 & 0.62 & 0.67 \\
\hline 19 & $\mathrm{AC} 2 \mathrm{E} 005 \mathrm{C}$ & 1769 & 1841 & & 0.73 & 0.69 & 0.51 & 0.52 \\
\hline 20 & AC2E006A & 1765 & 1841 & & 0.77 & 0.65 & 0.66 & 0.61 \\
\hline 21 & $\mathrm{AC} 2 \mathrm{E} 006 \mathrm{~B}$ & 1779 & 1842 & & 0.76 & 0.76 & 0.57 & 0.58 \\
\hline 22 & AC2E007A & 1780 & 1841 & & & 0.75 & 0.56 & 0.57 \\
\hline 23 & AC2E007C & 1774 & 1841 & & 0.82 & 0.79 & 0.65 & 0.61 \\
\hline 24 & AC2E008A & 1779 & 1840 & & 0.58 & 0.55 & 0.51 & 0.51 \\
\hline 25 & $\mathrm{AC} 2 \mathrm{~S} 002 \mathrm{~A}$ & 1766 & 1838 & & 0.74 & 0.70 & 0.61 & \\
\hline 26 & $\mathrm{AC} 2 \mathrm{~S} 002 \mathrm{~B}$ & 1761 & 1840 & & 0.75 & 0.56 & 0.48 & 0.48 \\
\hline 27 & $\mathrm{AC} 2 \mathrm{~S} 003 \mathrm{C}$ & 1777 & 1841 & & 0.64 & 0.65 & 0.40 & $0.34 \mathrm{~A}$ \\
\hline 28 & $\mathrm{AC} 2 \mathrm{~S} 004 \mathrm{~B}$ & 1764 & 1841 & & 0.53 & 0.46 & 0.47 & 0.49 \\
\hline 29 & $\mathrm{AC} 2 \mathrm{~S} 006 \mathrm{~A}$ & 1774 & 1842 & & 0.51 & 0.57 & $0.51 \mathrm{~B}$ & $0.52 \mathrm{~B}$ \\
\hline 30 & AC2W003A & 1769 & 1841 & & 0.70 & 0.72 & 0.83 & 0.84 \\
\hline 31 & AC2W005A & 1765 & 1841 & & 0.81 & 0.80 & 0.67 & 0.71 \\
\hline 32 & AC2W007A & 1754 & 1842 & 0.84 & 0.84 & 0.84 & 0.72 & 0.75 \\
\hline 33 & AC2W007B & 1768 & 1842 & & 0.73 & 0.84 & 0.63 & 0.56 \\
\hline 34 & $\mathrm{AC} 2 \mathrm{~W} 007 \mathrm{C}$ & 1756 & 1842 & 0.81 & 0.82 & 0.82 & 0.74 & 0.75 \\
\hline 35 & AC2W008A & 1764 & 1841 & & 0.76 & 0.70 & 0.69 & 0.65 \\
\hline 36 & $\mathrm{AC} 2 \mathrm{~W} 008 \mathrm{C}$ & 1760 & 1840 & & 0.84 & 0.77 & 0.64 & 0.66 \\
\hline 37 & AC2W008D & 1770 & 1840 & & 0.83 & 0.79 & 0.79 & 0.79 \\
\hline 38 & ACME007B & 1770 & 1841 & & 0.75 & 0.66 & 0.52 & 0.54 \\
\hline 39 & ACMW007A & 1775 & 1841 & & 0.57 & 0.58 & 0.51 & 0.47 \\
\hline \multicolumn{4}{|c|}{ Average Segment Correlation } & 0.81 & 0.72 & 0.68 & 0.60 & 0.59 \\
\hline
\end{tabular}

'An "A" or "B" in these columns indicates a 40-yr segment flagged by COFECHA, but no dating adjustment was necessary. ${ }^{2}$ "End Year" is the last measurable ring, and will differ from the "Outer Ring" in Table 2.

A graphical comparison confirmed the crossdating between the chronology developed from the Alfred's Cabin cores and the Norris Basin reference chronology (Figure 5). The tree-ring chronology from Alfred's Cabin spans the years 1749 to 1842 . Certain marker rings and "couplets" of rings (such as the years 1755, 1772 and 1773, 1784 and 1785, 1792 and 1794, 1813 and 1816, and 1836) are clearly present in both the Alfred's Cabin cores and the Norris Basin reference chronology. Some inconsistencies among the rings were present between the two data sets (such as the 


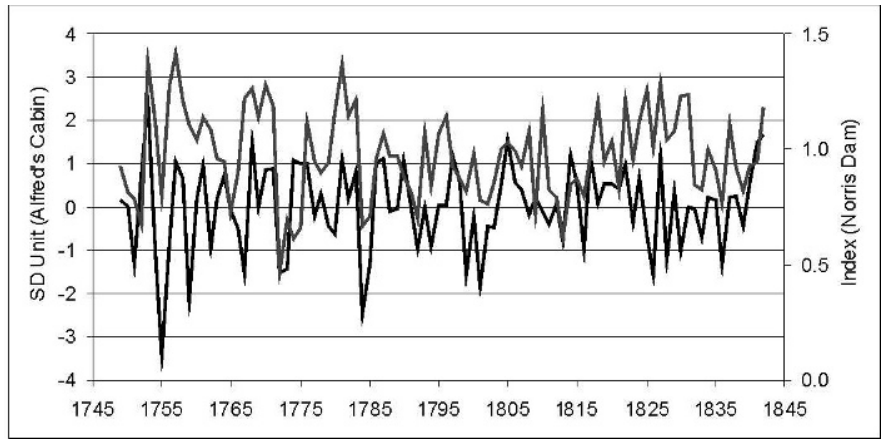

Figure 5. Crossdating between the Alfred's Cabin master dating chronology created by COFECHA (black line) and the Norris Basin reference chronology (blue line) from 1749 to $1842(\mathrm{r}=0.45, \mathrm{n}=94 \mathrm{yrs}, \mathrm{t}=4.83, \mathrm{p}<0.0001)$.

rings for 1774, 1809 and 1810, and 1821), but these could be caused by fluctuations in local climate patterns, and do not override the clear regional signal in common between these two sets of tree rings. The correlation coefficient calculated by COFECHA between the Alfred's Cabin and Norris Dam standard chronologies was highly significant $(\mathrm{r}=0.45, \mathrm{n}=94 \mathrm{yrs}, \mathrm{t}=4.83, \mathrm{p}<0.0001)$, further substantiating that the tree rings in the logs from Alfred's Cabin are absolutely anchored in time.

\section{DISCUSSION}

Outermost dates for the cores from Alfred's Cabin range from 1841 to 1843 (Table 2), which

Table 2. Cutting Dates for Logs in Alfred's Cabin.

\begin{tabular}{|c|c|c|c|}
\hline $\log$ & Outer Ring & Outer Ring Type ${ }^{1}$ & Inferred Period of Cutting \\
\hline AC1E006 & 1842 & $\mathrm{v}$ & Close to cutting date, outermost ring likely missing. \\
\hline AC1E008 & 1843 & $\mathrm{r}$ & 1843 earlywood present to middle of ring. Tree cut in summer 1843. \\
\hline AC1N002 & 1843 & $\mathrm{r}$ & 1843 earlywood present to middle of ring. Tree cut in summer 1843. \\
\hline AC1N003 & 1843 & $\mathrm{r}$ & 1843 latewood present. Cut sometime between fall 1843 and spring 1844. \\
\hline AC1N005 & 1841 & $\mathrm{r}$ & 1841 latewood present. Cut sometime between fall 1841 and spring 1842. \\
\hline AC1N006 & 1841 & $\mathrm{r}$ & 1841 latewood present. Cut sometime between fall 1841 and spring 1842. \\
\hline AC1N007 & 1842 & $\mathrm{r}$ & 1842 latewood present. Cut sometime between fall 1842 and spring 1843. \\
\hline AC1W006 & 1842 & $\mathrm{r}$ & 1842 latewood present. Cut sometime between fall 1842 and spring 1843. \\
\hline AC1W007 & 1842 & $\mathrm{r}$ & 1842 latewood present. Cut sometime between fall 1842 and spring 1843. \\
\hline AC1W008 & 1842 & $\mathrm{r}$ & 1842 earlywood present to middle of ring. Tree cut in summer 1842 . \\
\hline $\mathrm{AC} 2 \mathrm{E} 004$ & 1843 & $\mathrm{r}$ & 1843 earlywood present to early part of ring. Tree cut in spring 1843. \\
\hline $\mathrm{AC} 2 \mathrm{E} 005$ & 1842 & $\mathrm{r}$ & 1842 latewood present. Cut sometime between fall 1842 and spring 1843. \\
\hline $\mathrm{AC} 2 \mathrm{E} 006$ & 1843 & $\mathrm{r}$ & 1843 earlywood present to early part of ring. Tree cut in spring 1843 . \\
\hline $\mathrm{AC} 2 \mathrm{E} 007$ & 1842 & $\mathrm{r}$ & 1842 latewood present. Cut sometime between fall 1842 and spring 1843. \\
\hline AC2E008 & 1842 & $\mathrm{r}$ & 1842 earlywood present to early part of ring. Tree cut in spring 1842. \\
\hline $\mathrm{AC} 2 \mathrm{~S} 002$ & 1842 & $\mathrm{r}$ & 1842 earlywood present to early part of ring. Tree cut in spring 1842. \\
\hline $\mathrm{AC} 2 \mathrm{~S} 003$ & 1842 & $\mathrm{r}$ & 1842 earlywood present to middle of ring. Tree cut in summer 1842. \\
\hline $\mathrm{AC} 2 \mathrm{~S} 004$ & 1842 & $\mathrm{r}$ & 1842 earlywood present to middle of ring. Tree cut in summer 1842. \\
\hline AC2S006 & 1843 & $\mathrm{r}$ & 1843 earlywood present to late part of ring. Tree cut in late summer 1843 . \\
\hline $\mathrm{AC} 2 \mathrm{~W} 003$ & 1842 & $\mathrm{r}$ & 1842 latewood present. Cut sometime between fall 1842 and spring 1843. \\
\hline AC2W005 & 1842 & $\mathrm{r}$ & 1842 latewood present. Cut sometime between fall 1842 and spring 1843. \\
\hline AC2W007 & 1843 & $\mathrm{r}$ & 1843 earlywood present to middle of ring. Tree cut in summer 1843. \\
\hline AC2W008 & 1843 & $\mathrm{r}$ & 1843 earlywood present to middle of ring. Tree cut in summer 1843. \\
\hline ACM007 & 1842 & $\mathrm{r}$ & 1842 latewood present. Cut sometime between fall 1842 and spring 1843. \\
\hline
\end{tabular}

${ }^{1} \mathrm{r}$ : outermost ring is continuous and intact around a smooth surface, but no bark is present (considered a cutting date).

v: the date is within a few years of the cutting date (supports a later cutting date). 
reflect the outermost ring present on any core, whether complete or partial. Because the outermost ring was intact on all but one log that was sampled, the range of outermost dates most likely occurred because the trees were harvested over a period of 2 to 3 years. By far, the majority of cores showed outer ring dates of 1842 and 1843. These dates suggest cutting dates within a fairly confined window, from fall of 1842 (around October, or the beginning of the dormant season after the 1841 ring had completely formed) to the spring of 1843 (March to June, because the earlywood for 1843 was present on many cores). On no series did we find evidence for latewood formation in 1843, indicating that tree harvesting had concluded by spring or early summer of 1843 . The series that show outermost dates of 1841 (cutting dates from fall of 1841 to spring of 1842) could well have been cut in 1843 because the outermost surface was too eroded to make the 1842 ring clear enough to measure. After visually inspecting the differences in the outer surfaces between the 1841 cores and the 1842 cores, we feel that this is a likely explanation.

The shorter 40-year segments in the 39 series included in the Alfred's Cabin master chronology have very high correlations with each other (Table 1), which otherwise would not be possible if correct internal dating had not been established. These high correlations were surprising for treering sequences of eastern red cedar, a species that traditionally has posed problems for dendrochronologists in the Southeastern U.S. because of its propensity to form false rings (in the form of expanded latewood). The quality of the crossdating between the Alfred's Cabin master chronology and the Norris Basin eastern red cedar reference chronology, coupled with the internal crossdating between samples taken from the cabin itself, are compelling evidence that Alfred's Cabin is correctly anchored in time and was built while Alfred Jackson was enslaved, with final construction and possible permanent occupation likely occurring in spring or summer of 1843 .

Confirming that this double-pen log cabin was constructed as a slave cabin during the lifetime of President Andrew Jackson (17671845) was crucial in planning the building's future restoration. Although occupied by former slave
Alfred Jackson after the Civil War, the cabin's early history was a mystery. The State purchased the property in 1855 and turned it over to the Ladies' Hermitage Association to operate as a historic site museum in 1889 . Over the years, the National Historic Landmark cabin was preserved and interpreted as Alfred Jackson's home, but restoration techniques and treatments were inconsistent because of the gap in information regarding the building's origins and early history. This is in contrast to the majority of The Hermitage property, which is generally restored and interpreted as a Jacksonian Era plantation landscape from the 1830s and 1840s. With the mystery now solved, Alfred's Cabin can be accurately restored and interpreted as one of only a handful of authentic Jacksonian Era slave cabins remaining in Tennessee and the American South.

\section{ACKNOWLEDGMENTS}

The Alfred's Cabin Dendrochronology Study at The Hermitage was funded in part by a grant from the Charles Evans Hughes Preservation Fund of the National Trust for Historic Preservation. We gratefully acknowledge the support offered by the very accommodating staff at The Hermitage throughout all stages of this project. We were kindly assisted in the field by Georgina DeWeese, Tim Green, Jessica Slayton, and Shannon Koerner, all of whom gave freely of their time to help on this project.

\section{REFERENCES CITED}

Ahlstrom, R. V. N., J. S. Dean, and W. J. Robinson, 1991. Evaluating tree-ring interpretations at Walpi Pueblo, Arizona. American Antiquity 56(4):628-644.

Bannatyne, L., 2005. Every tree has a story to tell. Christian Science Monitor. March 8, 2005.

Baskin, J. M., and C. C. Baskin, 2004. History of the use of "cedar glades" and other descriptive terms for vegetation on rocky limestone soils in the Central Basin of Tennessee. Botanical Review 70(4):403-424.

Bekker, M. F., and D. M. Heath, 2007. Dendroarchaeology of the Salt Lake Tabernacle, Utah. Tree-Ring Research 63(2): 99-104.

Bortolot, Z. J., C. A. Copehneaver, R. L. Longe, and J. A. N. van Aardt, 2001. Development of a white oak chronology using live trees and a post-Civil War cabin in south-central Virginia. Tree-Ring Research 57:197-203. 
Bowers, L. J., and D. L. Grashot, 1976. Results of the First Hermitage dendrochronological study. In An Archaeological and Historical Assessment of the First Hermitage, edited by S. D. Smith, pp. 271-281. Division of Archaeology, Tennessee Department of Conservation, and The Ladies' Hermitage Association, Nashville, Tennessee.

Chase, S., 1999. First Hermitage Restoration \& Alfred's Cabin: Finish Analysis. Report on file at The Hermitage, Nashville.

Dean, J. S., 1997. Dendrochronology. In Chronometric Dating in Archaeology, edited by R. E. Taylor, and M. J. Aitken, pp. 31-64. Advances in Archaeological and Museum Science 2.

Forest Products Laboratory, 1974. Wood Handbook: Wood as an Engineering Material. USDA Forest Service Handbook 72.

Fritts, H. C., 1976. Tree Rings and Climate. Academic Press, New York.

Grissino-Mayer, H. D., 2001. Evaluating crossdating accuracy: A manual and tutorial for the computer program COFECHA. Tree-Ring Research 57:205-221.

Grissino-Mayer, H. D., and H. C. Fritts, 1997. The International Tree-Ring Data Bank: Growth and Adaptation to the World Community. Final Report, Paleoclimatology Program, National Oceanic and Atmospheric Administration, Boulder, Colorado.

Grissino-Mayer, H. D., and S. L. van de Gevel, 2007. Tell-tale trees: The historical dendroarchaeology of log structures at Rocky Mount, Piney Flats, Tennessee. Historical Archaeology 41(4):30-47.

Hawley, F. M., 1937. Relationship of southern cedar growth to precipitation and run off. Ecology 18(3):398-405.

— 1938. Dendrochronology in two Mississippi drainage tree-ring areas. Tree-Ring Bulletin 5(1):3-7.

- 1941. Tree Ring Analysis and Dating in the Mississippi Drainage. Publications in Anthropology Occasional Paper 2. University of Chicago Press, Chicago.

Heikkenen, H. J., 2001. The Year of Construction of the First Hermitage and Kitchen as Derived by Key-Year Dendrochronology. Report on file at The Hermitage, Nashville.

Henderson, J. P., H. D. Grissino-Mayer, S. L. van de Gevel, and J. L. Hart, 2009. The historical dendroarchaeology of the Hoskins House, Tannenbaum Historic Park, Greensboro, North Carolina, U.S.A. Tree-Ring Research 65:37-45.

Holmes, R. L., 1983. Computer-assisted quality control in treering dating and measurement. Tree-Ring Bulletin 43:69-78.

McKee, L., 1997. Summary Report on the 1994 Excavation around Alfred's Cabin at The Hermitage. Report on file at The Hermitage, Nashville.

Jones, R., 2002. The Hermitage Cultural Resources Inventory: Alfred's Cabin. Report on file at The Hermitage, Nashville.

Jones, R. D., 2006. Alfred's Cabin Dendrochronology Study. Final Report to the National Trust for Historic Preservation, Preservation Services Fund.

Lassetter, R., 1938. A Dendrochronological Investigation in the Clinch River Drainage, Tennessee, M.A. thesis, The University of Tennessee, Knoxville.

Mann, D. F., 2002. The Dendroarchaeology of the Swaggerty Blockhouse, Cocke County, Tennessee, M.S. thesis, The University of Tennessee, Knoxville.

McCrea, W. J., 1995. Dendrochronology: A new research tool. North Carolina Preservation 99:3-7.
McKee, L., 2000. The archaeological study of slavery and plantation life in Tennessee. Tennessee Historical Quarterly 59(3): 188-203.

Nash, S. E., 2000. Seven decades of archaeological tree-ring dating. In It's About Time: A History of Archaeological Dating in North America, edited by S. E. Nash, pp. 60-82. University of Utah Press, Salt Lake City.

National Park Service, 1999. Historic American Building Survey: Alfred's Cabin at The Hermitage. Report on file in Washington, D.C. and at The Hermitage, Nashville.

Nielsen, E., G. Conley, and K. D. McLeod, 1995. The use of tree-ring analysis to determine the construction date of historic buildings in southern Manitoba. Manitoba Archaeological Journal 5(2):46-59.

Orvis, K. H., and H. D. Grissino-Mayer, 2002. Standardizing the reporting of abrasive papers used to surface tree-ring samples. Tree-Ring Research 58(1/2):47-50.

Pulice, M. J., 2000. The Log Outbuilding at Solitude: An Architectural and Archaeological Investigation of Virginia Tech's Second Oldest Building, M.S. thesis, Virginia Polytechnic Institute and State University, Blacksburg.

Reding, W. M., 2002. Assessment of Spatial and Temporal Patterns of Log Structures in East Tennessee, M.S. thesis, The University of Tennessee, Knoxville.

Reed, D., 2000. Construction Analysis of the First Hermitage and Alfred's Cabin. Report on file at The Hermitage, Nashville.

Robinson, W. J., 1976. Tree-ring dating and archaeology in the American southwest. Tree-Ring Bulletin 36:9-20.

Rosman, K., 2005. This not-so-old house. Wall Street Journal. April 8, 2005.

Slayton, J. D., M. R. Stevens, H. D. Grissino-Mayer, and C. H. Faulkner, 2009. The historical dendroarchaeology of two log structures at the Marble Springs Historic Site, Knox County, Tennessee. Tree-Ring Research 65:23-36.

Stahle, D. W., 1979. Tree-ring dating of historical buildings in Arkansas. Tree-Ring Bulletin 39:1-28.

Stahle, D. W., M. K. Cleaveland, and J. G. Hehr, 1988. North Carolina climate changes reconstructed from tree rings: A.D. 372 to 1985 . Science 240:1517-1519.

Stokes, M. A., and T. L. Smiley, 1996. An Introduction to TreeRing Dating. University of Arizona Press, Tucson.

Swetnam, T. W., M. A. Thompson, and E. K. Sutherland, 1985. Using Dendrochronology to Measure Radial Growth of Defoliated Trees. USDA Forest Service Agricultural Handbook 639 .

The Hermitage, 2008. http://www.thehermitage.com. Accessed 26 August, 2008.

Towner, R. H., 2002. Archaeological dendrochronology in the Southwestern United States. Evolutionary Anthropology 11: 68-84.

Wight, G. D., and H. D. Grissino-Mayer, 2004. Dendrochronological dating of an Antebellum Period House, Forsyth County, Georgia, U.S.A. Tree-Ring Research 60:91-99.

Yamaguchi, D. K., 1991. A simple method for cross-dating increment cores from living trees. Canadian Journal of Forest Research 21:414 416 .

Received 3 July 2008; accepted 8 September 2008. 